\title{
Pre-Service Teachers' Levels of Adaptations to Remote Teaching and Learning at A University in A Developing Country in the Context of COVID-19
}

\author{
Lydia Mavuru $^{1}$, Oniccah Koketso Pila ${ }^{2} \&$ Anesu Gelfand Kuhudzai ${ }^{3}$ \\ ${ }^{1,2,3}$ Department of Science and Technology Education, University of Johannesburg, South Africa \\ Correspondence: Lydia Mavuru, Department of Science and Technology Education, University of Johannesburg, \\ South Africa.
}

Received: May 5, 2021

Accepted: June 29, 2021

Online Published: June 30, 2021

doi:10.5430/ijhe.v11n1p12

URL: https://doi.org/10.5430/ijhe.v11n1p12

\begin{abstract}
The outbreak of Covid-19 pandemic has not only caused fear and uncertainty in the education systems across the globe, but it brought about a fundamental paradigm shift in the mode of teaching and learning. Higher education drastically transitioned to remote/ online delivery even for the students who had enrolled for face-to-face mode of teaching and learning. The paper is premised in the context of a developing country that such a drastic change could have widened the digital divide between students from privileged homes and those from disadvantaged families as students did not receive adequate technological training and to even acquire the necessary electronic devices. Consequently, the study sought to establish the levels of adaptation to remote teaching and learning by university students herein referred to as pre-service teachers. Following a quantitative research design, an online questionnaire survey was administered to 157 pre-service teachers enrolled in a Life Sciences Methodology module at a South African university. Data was analysed using SPSS version 26 and descriptive statistics, exploratory analysis of the questionnaire constructs and One-Way ANOVA tests were conducted to compare pre-service teachers` perceptions, experiences and preparedness. The results showed that the disparities and inequalities that exist in different South African contexts in which pre-service teachers hail from, dictated their levels of adaptations to remote teaching and learning. Those from disadvantaged backgrounds were less adapted as they struggled more when it comes to acquisition of electronic gadgets and connectivity to facilitate remote learning compared to those from advantaged backgrounds. This study affirms the call for education institutions and governments to rethink ways of closing the gap between the poor and the rich in education in terms of resource and other support mechanisms.
\end{abstract}

Keywords: adaptation, COVID-19, developing country, pre-service teachers, remote teaching and learning

\section{Introduction}

\subsection{Background and Problem Statement}

Online instruction has become a reality as higher education redefines the mode of teaching and learning in light of COVID-19 pandemic. Before the pandemic, there has been an increase in popularity of online programmes in higher education as evidenced by the offering of distance courses (Ananga \& Biney, 2017) and online courses (Singh \& Thurman, 2019). Despite the conceptions of the benefits of online instruction and the global trends in technological developments, most university instructors and students have preferred to remain in their comfort zone of face-to-face instruction (Fish \& Gill, 2009; Majid, Yang, Lei, \& Haoran, 2014). Different stakeholders have called on universities and high schools to foster innovation and creativity to ensure adequate preparation of graduates for the ever changing demands of work places. Consequently, the advent of the Fourth Industrial Revolution underscores the need to develop teachers with skills to captalise on the "infusion of technologies and their interaction" (Schwab, 2016, p.12) so they can cope with the demands of the ever changing technological environment. Teacher educators therefore should fully embrace digital transformation in its broadest sense with a view to foster pedagogic innovation in various instructional settings.

New technologies such as wikis, blogs, social networking, can provide pre-service teachers with more platforms for collaboration, interaction, communication, co-creation and sharing of ideas and knowledge (Hartshorne \& Ajjan, 2009; Shihab, 2008). As such, in a study by Sadaf, Newby and Ertmer (2012) to determine the perceptions of pedagogical benefits and use of Web 2.0 technologies, pre-service teachers indicated that the use of technologies 
provided them with many benefits. These benefits included improvement in interactions, increased satisfaction with the course and improved critical thinking skills during collaboration. More benefits of online teaching and learning include the affordances of individuals with opportunities of working in own space and time (Li \& Akins, 2005), independence, and development of higher order thinking skills on the part of students (Kohler, et al., 2004). ICT integration in education also fosters the development of 21 st century skills such as collaboration, problem-solving, decision-making, critical thinking, creativity and innovation (Ciroma, 2014). Despite all these benefits, successful ICT integration still faces numerous hindrances (Rabah, 2015). This grim reality necessitated the investigation of pre-service teachers' perceptions, experiences and preparedness in engaging with remote teaching and learning, a practice they were not accustomed to. Teachers' attitudes have been found to influence their implementation of an innovation (Paulikas, 2018). This is in light of the realities that although the key pedagogic affordances of ICT integration are largely appreciated, many teachers still encounter formidable challenges when using ICT in their classrooms. For instance, successful online teaching requires skills in using different technologies and yet early studies have shown that technology is perceived to be stressful (e.g. Young, Cantrell \& Shaw, 2001). In addition, lack of confidence in online teaching and learning (Hinson \& LaPrairie, 2005) and inadequate experience in online delivery (Britt, 2006; Koehler et al., 2004), have been raised.

With the onset of the COVID-19 pandemic, most universities and some schools, both primary and secondary engaged in remote and online teaching and learning. There have been recent publications on online or remote teaching and learning which are of importance to institutions of higher learning in developing countries. Most have focused on comparing remote teaching with online learning (e.g. Hodges et al., 2020); the need for online and remote learning in response to COVID-19 pandemic (e.g. Ali, 2020); digital transformation of education due to the pandemic (e.g. Mhlanga \& Moloi, 2020); online learning in the context of rural institutions (Dube, 2020); and sustainability and implications of online learning on higher education (Coman et al., 2020). However very little has been done to establish the perceptions and experiences of the recipients of the sudden transition from face-to-face to remote teaching and learning. In the current study, the pre-service teachers were enrolled in a face-to-face classroom-based university course. Amid COVID-19 pandemic, there was a sudden change from the 'normal' to remote teaching and learning. Whilst it has become mandatory for institutions to embrace online or remote mode of teaching and learning, UNESCO (2020b) confirmed possible challenges due to the fact that only $20 \%$ of households in South West Asia and sub-Saharan Africa have internet connectivity. This calls for a need to determine the pre-service teachers' level of adaptation to engage in remote teaching and learning. The overarching research question is: To what extent are pre-service teachers adapted to remote teaching and learning? and answers to the following sub research questions were sought:

1. What are pre-service teachers' perceptions and experiences regarding remote teaching and learning?

2. How do pre-service teachers' perceptions and experiences of remote teaching and learning relate to their level of adaptation to the sudden transition from face-to-face to remote teaching and learning?

3. What are the pre-service teachers' conceptions about their preparedness to teach their own learners remotely?

4. How do the pre-service teachers' adaptations compare across their different learning environments?

\subsection{Justification of the Study}

The article is aimed at establishing the pre-service teachers' levels of adaptation to remote teaching and learning. The transition to remote mode occurred abruptly without according the students any form of training. They had to adapt to new learning technological platforms, change in assessment strategies whilst grappling with the new expectations of technological knowledge and skills and acquisition of appropriate technological gadgets became mandatory. The argument is that such a drastic change in the mode of teaching and learning could have widened the digital divide between students from privileged homes and those from disadvantaged families. The pre-service teachers' adaptation towards remote teaching and learning mode, whose measurement is based on how they perceived, experienced and felt prepared to engage on remote teaching and learning, are not due to intellectual abilities, but due to logistical challenges they faced.

While the article aimed on the one hand to capture the pre-service teachers' levels of adaptation to the new norm, it also aimed to shed light on how teacher educators can best adapt their remote teaching, assessment and assistance for their students. Findings from such a study contribute towards the general phenomena of 'blended' and 'online learning' from the perspective and context of a developing country. 


\subsection{Comparison between Face- to- Face and Remote Teaching and Learning}

Online teaching and learning has grown tremendously in the past decade (Allen \& Seaman, 2017; Chiasson, Teras \& Smart, 2015). In response to the COVID-19 pandemic as well as the initiative to combat the spread of the coronavirus, higher institutions of learning had to initiate the shift from face-to-face to remote teaching and learning (Ali, 2020). It is therefore evident that the COVID-19 pandemic has promoted the digital transformation in the education sector resulting in the increased use of 4th industrial revolution (4IR) tools to conduct online teaching and learning (Mhlanga \& Moloi, 2020).

Because of the uncertainties of the future, society requires a flexible and a resilient education system (Ali, 2020). Most universities therefore have embraced the paradigm shift to online teaching and learning, consequently redefining teaching (Fish \& Gill, 2009). Online delivery provides opportunities for the transformation of educational landscapes and also potential for the development of innovative pedagogical approaches (Platt, Raile \& Yu, 2014).

Though perceptions vary amongst individual students, previous studies reported students' positive perceptions regarding the convenience and flexibility afforded by remote modes of instruction (e.g. Fidalgo, Thorman, Kulyk, \& Lencastre, 2020; Leasure, Davis \& Thievon, 2000). However, students with limited previous exposure to online courses perceived remote instruction to be ineffective whereas those with experience perceived online instruction as offering the desired learning space (Allen \& Seaman, 2010). Despite the preference of online teaching and learning due to its convenience, most students insisted that face-to face instruction provides more advanced levels of interaction with the instructors and immediate feedback compared to online instruction (Platt, Raile \& Yu, 2014). The argument is that face-to-face teaching and learning results in more knowledge gains when compared to online instruction (Hoerspool \& Yang, 2010). Notwithstanding the flexibility of online instruction, greater responsibility is mandatory for accomplishing the intended learning outcomes, which therefore demands self-discipline on the individual students to ensure completion of the course and to perform well (Deimann \& Bastiaens, 2010).

The shift to remote/online teaching and learning has proved to be an important move in some countries. An example is of China which coined the transition 'Suspending Classes without Suspending Learning' initiative to escape compromising learning throughout the pandemic (Zhang et al., 2020). Likewise, the Chinese government declared the 'Disrupted classes, Undisrupted Learning' strategy to afford students an opportunity to learn in the comfort and safety of their own homes (Huang, Liu, Tlili, Yang, Wang \& Chang, 2020). Similarly, in South Africa many universities amended the mode of teaching to remote instruction (Mhlanga \& Moloi, 2020).

The transition from face-to-face to remote/online teaching and learning is a challenging process as it requires exploration of remote practices that are suitable for both the instructor and the students (Hinson \& LaPrairie, 2005). Because proficiency in technology use is important, perceptions of remote instruction differs amongst individuals at different levels of technological knowledge and skills. Use of different technological tools and implementing relevant pedagogical strategies have been identified as processes that may hinder the successful enactment of remote teaching and learning (Chiasson et al., 2015). As such, in a study to evaluate university lecturers' perceptions of online instruction, Fish and Gill (2009) found that those who had online experiences equated online instruction to face-to-face whereas those who lacked experience showed preference for face-to-face instruction. However, Chohan (2014) noted that there are processes that are more achievable in remote teaching and learning platforms than in a face-to-face mode and vice versa. For instance, higher levels of student-instructor interactions have been evident in a face-to-face platform compared to remote/online platforms (Platt, Raile, \& Yu, 2014) and to this Levy (2005) bemoaned that there is less engagement in online instruction which may lead to increased dropout rates. On the other hand, most students perceived online instruction to be more flexible and convenient than face-to-face (Platt, Raile \& $\mathrm{Yu}, 2014$; Srichanyachon, 2014) and that the cost of travelling is minimised.

\subsection{Challenges Associated with Remote Teaching and Learning}

Whilst technology, electronic gadgets and connectivity are the main components of remote teaching and learning, the context in South Africa is not conducive for all pre-service teachers to access all the components. Accordingly, Taylor and Yu (2009) regarded South Africa as a highly unequal society in terms of students' affordances of the requirements of remote teaching and learning. Because of lack of the technological necessities in a remote mode of teaching and learning, Srichanyachon (2014) found delayed acceptance of the online mode due to poor electronic gadgets since the suitable gadgets are costly and due to unreliable internet connectivity. Remote teaching and learning is therefore impeded because students from poor socio-economic backgrounds cannot afford the costly gadgets and meaningful connectivity (Bharuthram \& Kies, 2012; Letseka, Letseka \& Pitsoe, 2018). 


\subsection{Theoretical Frameworks}

This study is underpinned by two theoretical frameworks. The Technology Acceptance Model (TAM) (Venkatesh \& Davis, 1996), which explains the willingness of individuals to use technology based on perceived usefulness and perceived ease of use. The model will be used in explaining the pre-service teachers' perceptions regarding remote/online teaching and learning. Figure 1 shows the variables that influence the choices an individual makes in terms of behaviour (Venkatesh \& Davis, 1996).

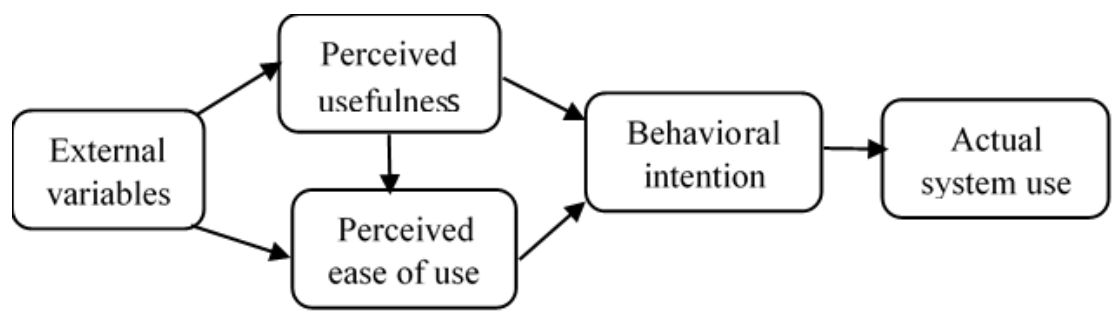

Figure 1. Final version of TAM (Venkatesh \& Davis, 1996)

The study is also underpinned by the constructivist learning philosophy (Briggs, 1987; 1993). Constructivists proffer that deep learning occurs only if the student is actively engaged in managing the mental processes in response to new information. In essence, constructivism is focused on the student constructing own knowledge and understanding rather than regurgitating what has been taught (Herrington \& Standen, 2000). This theory is the critical lens through which pre-service teachers' experiences of remote teaching and learning could be established and also the extent to which pre-service teachers perceived their lecturers' initiation and facilitation of the construction of own knowledge and how they were guided to ensure conceptual understanding (Roddy et al., 2017). Social constructivism by its very nature acknowledges that meaningful learning takes place through interactions of people in a group (Vygotsky, 1986). A point to note is that teacher education in South Africa has been blamed for its failure to bridge the theory-practice gap, implying that it is too theory-based and that it renegades practice to the classroom (Kinsella \& Pitman, 2012).

\section{Method}

\subsection{Research Design}

Quantitative survey design was adopted (Creswell, 2014) to collect measurable data (Park \& Park, 2016), which in this article refers to the teachers' levels of adaptations to remote teaching and learning. Firstly, a five point Likert scale questionnaire was designed. The survey instrument sought the pre-service teachers' biographical information which relates to their learning environment at home; and their perceptions, experiences and preparedness regarding remote teaching and learning. The assumption is that how teachers perceived, experienced and displayed level of preparedness with regards to remote mode of teaching and learning would shed light on their levels of adaptation.

\subsection{Selection of Participants}

All pre-service teachers enrolled for Life Sciences Methodology and Practicum course in a South African university were selected in the census survey. The sample comprised of 84 fourth year and 63 third year Bachelor of Education students, and 10 postgraduate certificate in education students to make a total of 157 pre-service teachers. In the South African context, the majority of these students come from disadvantaged backgrounds in terms of socio-economic status, which is an important issue in the current article where the abrupt transition from face-to-face to remote teaching and learning required students to acquire electronic devices.

\subsection{Data Collection}

Data collection involved administering the questionnaire to all the 157 pre-service teachers via online as a google questionnaire. The questionnaire sought pre-service teachers' biographical information which relates to their remote teaching and learning environment, their perceptions and experiences on remote mode and their preparedness to also teach their learners remotely after obtaining the teacher qualification. A high response rate of $79.6 \%$ was achieved probably because the participants took it as an opportunity for them to share their feelings and experiences. For ethical reasons an ethical clearance certificate (Sem 2-2020-073) was obtained from the university and all the participants completed a consent form.

\subsection{Data Analysis}

Data was analysed using SPSS version 26. Rigorous analysis of data process involved: descriptive statistics for the biographical information; exploratory factor analysis for perceptions, experiences and preparedness as a dimension 
reduction technique; and One-Way ANOVA tests were conducted in order to compare pre-service teachers` perceptions, experiences and preparedness across their residential areas, which are the pre-service teachers' learning environments when learning remotely. For reliability and validity purposes, the survey instrument was piloted with a group of 50 Bachelor of Education students who were not part of the sample for the study. Results from the pilot group were used to calculate internal reliability/consistency and ensure the readability of the questionnaire. A Cronbach's alpha of $\alpha>.82$ was obtained for all constructs and $>.72$ for all items.

\section{Results}

The results are presented in four sections, the pre-service teachers' biographical information; their perceptions and experiences in remote teaching and learning and pre-service teachers' preparedness to teach remotely. The third section is an exploratory factor analysis of the questionnaire and lastly the results from the inferential statistics (One-way ANOVA).

\subsection{Pre-Service Teachers' Biographical Information}

The pre-service teachers' biographical information provided the context in which the current paper is premised on.

Table 1. Composite frequency table with pre-service teachers' biographical details

\begin{tabular}{|c|c|c|c|}
\hline Characteristics & Category & $\mathrm{n}$ & Percentage \\
\hline \multirow[t]{3}{*}{ Gender } & Female & 69 & 55.2 \\
\hline & Male & 55 & 44.0 \\
\hline & Non response & 1 & 0.8 \\
\hline \multirow[t]{4}{*}{ Race } & Black & 113 & 91.1 \\
\hline & Coloured & 5 & 4.0 \\
\hline & Indian/Asian & 2 & 1.6 \\
\hline & White & 5 & 4.0 \\
\hline \multirow[t]{5}{*}{ Residential area } & Informal settlement & 2 & 1.6 \\
\hline & Rural & 36 & 28.8 \\
\hline & Farm & 1 & 0.8 \\
\hline & Township & 64 & 51.2 \\
\hline & Suburban & 22 & 17.6 \\
\hline \multirow[t]{4}{*}{ Electronic devices used } & Cell phone & 48 & 38.4 \\
\hline & Tablets/iPad & 6 & 4.8 \\
\hline & Laptop & 68 & 54.4 \\
\hline & Desktop & 3 & 2.4 \\
\hline \multirow[t]{2}{*}{ Source of connectivity } & Data & 101 & 80.8 \\
\hline & $\mathrm{Wi}-\mathrm{Fi}$ & 24 & 19.2 \\
\hline \multirow[t]{3}{*}{ Level of study } & Third year & 49 & 39.2 \\
\hline & Fourth year & 63 & 50.4 \\
\hline & $\begin{array}{l}\text { Postgraduate Certificate } \\
\text { in Education (PGCE) }\end{array}$ & 13 & 10.4 \\
\hline
\end{tabular}

From the composite frequency table 1 it shows that the majority of the pre-service teachers were Black Africans living in township schools and rural areas who relied on data for internet connectivity for them to access remote 
teaching and learning platforms. Townships are settlements which were reserved for the poor Black South African populace during apartheid and is characterised by overcrowding, a condition not suitable for effective learning. Whilst 54.4\% used laptops to access remote teaching and learning platforms, 38.4\% used cellphones, which were not user friendly due to the small screen.

\subsection{Pre-Service Teachers' Perceptions of Remote Teaching}

The pre-service teachers' perceptions of remote teaching and learning are presented in Table 2.

Table 2. Pre-service teachers' perceptions of remote teaching and learning

\begin{tabular}{|c|c|c|c|c|c|}
\hline Description of item & $\begin{array}{c}\text { Strongly } \\
\text { Agree/Agree }(\%)\end{array}$ & $\begin{array}{c}\text { Neutral } \\
(\%)\end{array}$ & $\begin{array}{c}\text { Disagree/ Strongly } \\
\text { Disagree }(\%)\end{array}$ & Mean & $\begin{array}{l}\text { Standard } \\
\text { deviation }\end{array}$ \\
\hline $\begin{array}{l}\text { I believe I can use technology } \\
\text { effectively for remote teaching and } \\
\text { learning. }\end{array}$ & 80.8 & 18.4 & 0.8 & 4.08 & 0.703 \\
\hline $\begin{array}{l}\text { I have the knowledge and ability to use } \\
\text { technologies during the remote } \\
\text { teaching of Life Sciences } \\
\text { Methodology module. }\end{array}$ & 83.1 & 15.3 & 1.6 & 4.07 & 0.723 \\
\hline $\begin{array}{l}\text { I do prefer remote teaching and } \\
\text { learning more than the face- to- face } \\
\text { we normally had. }\end{array}$ & 22.4 & 34.4 & 43.2 & 2.74 & 1.137 \\
\hline $\begin{array}{l}\text { I am challenged in terms of digital } \\
\text { competence. }\end{array}$ & 19.2 & 30.4 & 50.4 & 2.64 & 1.050 \\
\hline $\begin{array}{l}\text { I consider remote teaching as } \\
\text { beneficial. }\end{array}$ & 49.6 & 40.7 & 9.7 & 3.48 & 0.843 \\
\hline $\begin{array}{l}\text { The advantages of remote teaching and } \\
\text { learning outweigh the disadvantages. }\end{array}$ & 26.7 & 46.0 & 27.5 & 2.99 & 0.992 \\
\hline $\begin{array}{l}\text { I am in control of my own learning } \\
\text { during remote teaching and learning } \\
\text { process. }\end{array}$ & 76.6 & 14.5 & 8.9 & 3.94 & 0.899 \\
\hline $\begin{array}{l}\text { I believe remote teaching and learning } \\
\text { is effective in preparing me for the } \\
\text { teaching profession. }\end{array}$ & 60.4 & 24.2 & 15.3 & 3.60 & 0.995 \\
\hline $\begin{array}{l}\text { Though the shift from face-to-face to } \\
\text { remote teaching and learning happened } \\
\text { so suddenly, I had sufficient time to } \\
\text { prepare for the shift. }\end{array}$ & 29.9 & 29.0 & 41.1 & 2.85 & 1.141 \\
\hline $\begin{array}{l}\text { Remote learning challenged me in } \\
\text { terms of my digital competence. }\end{array}$ & 52.0 & 17.9 & 30.1 & 3.28 & 1.238 \\
\hline $\begin{array}{l}\text { Remote teaching and learning is } \\
\text { positively affecting my academic } \\
\text { performance in the Life sciences } \\
\text { methodology module. }\end{array}$ & 44.0 & 33.6 & 22.4 & 3.36 & 1.035 \\
\hline $\begin{array}{l}\text { I am satisfied with the platform } \\
\text { lecturers use to conduct remote } \\
\text { lectures. }\end{array}$ & 64.5 & 22.6 & 12.9 & 3.73 & 1.062 \\
\hline
\end{tabular}

Based on results in Table 2, the pre-service teachers were not so much confident in their technological knowledge and skills when learning through remote mode. The lack of confidence is noted in that whilst $83.1 \%$ agreed to possessing the technological knowledge and skills to learn through remote, 52\% agreed that they were challenged during remote learning because of their lack of digital competence. Quite a large percentage $(41.1 \%)$ showed dissatisfaction with the rapid transition from face-to-face to remote teaching and learning mode compared to only 
$29.9 \%$ who indicated that they had sufficient time to prepare for the shift from face-to-face to remote mode. To show the mixed feelings amongst pre-service teachers regarding their preferences, $46 \%$ had a neutral response to the statement: The advantages of remote teaching and learning outweigh the disadvantages. There is a lot of contradiction in the pre-service teachers' responses because whilst $43.2 \%$ preferred remote to face-to-face learning, there were $50.4 \%$ who acknowledged their lack of digital competence. Such contradictions could be that pre-service teachers realised the value of remote mode but they still preferred face-to-face mode. The fact that pre-service teachers' realised their shortcomings, showed that they were not well adapted to remote teaching and learning.

\subsection{Pre-Service Teachers' Experiences of Remote Mode of Teaching and Learning}

Table 3 presents results related to pre-service teachers' experiences of remote mode of teaching and learning.

Table 3. Pre-service teachers' experiences in remote teaching and learning

\begin{tabular}{|c|c|c|c|c|c|}
\hline Description of item & $\begin{array}{c}\text { Strongly } \\
\text { Agree/Agree }(\%)\end{array}$ & $\begin{array}{c}\text { Neutral } \\
(\%)\end{array}$ & $\begin{array}{c}\text { Disagree/ Strongly } \\
\text { Disagree }(\%)\end{array}$ & Mean & $\begin{array}{l}\text { Standard } \\
\text { deviation }\end{array}$ \\
\hline I have connectivity challenges. & 51.2 & 26.4 & 22.4 & 3.44 & 1.139 \\
\hline $\begin{array}{l}\text { I am coping well with remote } \\
\text { teaching and learning. }\end{array}$ & 38.4 & 42.4 & 19.2 & 3.23 & 1.041 \\
\hline $\begin{array}{l}\text { I am experiencing remote teaching } \\
\text { and learning in the } 21 \text { st century as I } \\
\text { expected. }\end{array}$ & 46.8 & 36.3 & 16.9 & 3.40 & 0.995 \\
\hline $\begin{array}{l}\text { I prefer the engagement in } \\
\text { discussions during remote lectures. }\end{array}$ & 42.8 & 37.1 & 20.2 & 3.31 & 0.923 \\
\hline $\begin{array}{l}\text { I prefer it when I am asked to make } \\
\text { contributions. }\end{array}$ & 44.4 & 38.7 & 16.9 & 3.29 & 0.961 \\
\hline $\begin{array}{l}\text { I prefer when I make comments on } \\
\text { the chat platform than talking. }\end{array}$ & 65.6 & 29.6 & 12.0 & 3.73 & 1.058 \\
\hline $\begin{array}{l}\text { I feel overwhelmed by the different } \\
\text { communication channels. }\end{array}$ & 28.4 & 26.0 & 45.5 & 2.83 & 1.077 \\
\hline $\begin{array}{l}\text { The use of a WhatsApp group } \\
\text { platform is very helpful. }\end{array}$ & 82.2 & 14.5 & 3.2 & 4.30 & 0.946 \\
\hline $\begin{array}{l}\text { I listen to the lecture recordings } \\
\text { posted on Blackboard. }\end{array}$ & 75.0 & 16.9 & 8.1 & 3.98 & 0.950 \\
\hline $\begin{array}{l}\text { My academic performance has } \\
\text { improved greatly during remote } \\
\text { teaching and learning process. }\end{array}$ & 36.3 & 41.1 & 22.5 & 3.15 & 0.955 \\
\hline $\begin{array}{l}\text { My lecturers show competency in } \\
\text { remote teaching and learning. }\end{array}$ & 78.4 & 18.4 & 3.2 & 4.06 & 0.816 \\
\hline $\begin{array}{l}\text { My lecturers come prepared for } \\
\text { remote teaching and learning. }\end{array}$ & 88.6 & 9.8 & 1.6 & 4.27 & 0.702 \\
\hline $\begin{array}{l}\text { My lecturers support me in this } \\
\text { remote teaching and learning. }\end{array}$ & 63.9 & 27.0 & 9.0 & 3.83 & 0.993 \\
\hline $\begin{array}{l}\text { I would prefer if lecturers just } \\
\text { upload materials on Blackboard } \\
\text { only without lectures on } \\
\text { Blackboard collaborate. }\end{array}$ & 11.2 & 18.4 & 70.4 & 2.03 & 1.143 \\
\hline $\begin{array}{l}\text { The Blackboard space has enough } \\
\text { material for each unit in the Life } \\
\text { Sciences Methodology module. }\end{array}$ & 76.8 & 20.8 & 2.4 & 4.13 & 0.823 \\
\hline $\begin{array}{l}\text { My lecturers show positive } \\
\text { attitudes about remote teaching and }\end{array}$ & 86.4 & 11.2 & 2.4 & 4.18 & 0.752 \\
\hline
\end{tabular}


learning.

The remote teaching and learning has distanced me from the lecturers.

I have a conducive learning environment at home for remote teaching and learning.

The online assessment given in Life sciences methodology prepares me for the teaching profession.

I receive effective feedback on the assessment from my lecturers.

The data I receive from the
41.0

24.2

72.8

52.8

72.8
33.6

28.2

21.6

28.8

16.0
25.5

47.5

5.6

18.4

11.2
3.25

2.65

1.163

university eases the financial strains.

The pre-service teachers indicated that they had meaningful remote teaching and learning experiences. As depicted in table 3 the majority indicated that they received materials, support, and feedback on assessments on their learning management system (Blackboard) from their lecturers who they perceived as being competent and always prepared for remote teaching sessions. More than half the participants (51.2\%) had connectivity challenges, which therefore could have affected their remote learning experiences. This is also confirmed by the $47.5 \%$ who indicated that their learning environment at home was not conducive for remote teaching and learning against only $24.2 \%$ who gave a positive response. The $36.3 \%$ who indicated that their academic performance improved greatly during remote teaching and learning process correspond to the $44.4 \%$ who had such perceptions in Table 2 . These experiences are however not convincing because $41.1 \%$ were neutral and $22.5 \%$ disagreed that their performance improved during remote teaching and learning. To show the poor adaptation, $38.4 \%$ of the pre-service teachers agreed that they were not coping well with remote teaching and learning and $42.4 \%$ having a neutral response. A closer analysis shows an alignment between pre-service teachers' perceptions and their experiences regarding their poor adaptation to remote teaching and learning.

Based on the pre-service teachers' experiences of remote teaching and learning, it shows that they preferred being given an opportunity to interact with others during remote lectures. For instance, $82.2 \%$ considered WhatsApp group platforms as helpful; $42.8 \%$ valued their engagement in discussions; whilst $42.4 \%$ and $44.4 \%$ appreciated the opportunity given to them to make contributions and making comments on the chat platform respectively. Such results show the importance of student involvement in the teaching and learning process, which is one of the imperatives of social constructivism.

\subsection{Pre-Service Teachers' Preparedness to Teach Remotely}

Because these pre-service teachers were enrolled for the Methodology and Practicum course which prepared them for the actual teaching and learning in the classrooms, they were also asked about their preparedness to teach their learners through online platforms. These questions were pertinent considering the unforeseen challenges the education system faced due to the COVID-19 pandemic. Results from pre-service teachers' responses are given in table 4. 
Table 4. Pre-service teachers' preparedness to teach remotely

\begin{tabular}{lccccc}
\hline \multicolumn{1}{c}{ Description of item } & $\begin{array}{c}\text { Strongly Agree } \\
\text { Agree (\%) }\end{array}$ & $\begin{array}{c}\text { Neutral } \\
(\%)\end{array}$ & $\begin{array}{c}\text { Disagree/ } \\
\text { Strongly } \\
\text { Disagree (\%) }\end{array}$ & Mean & $\begin{array}{c}\text { Standard } \\
\text { deviation }\end{array}$ \\
\hline $\begin{array}{l}\text { I believe I am capable to teach my } \\
\text { learners through remote platforms. }\end{array}$ & 65.6 & 30.4 & 4.0 & 3.78 & 0.792 \\
$\begin{array}{l}\text { I intend to teach my learners through } \\
\text { remote. }\end{array}$ & 36.8 & 46.4 & 16.8 & 3.25 & 0.981 \\
$\begin{array}{l}\text { I feel I can help my learners more when } \\
\text { I teach through remote than face-to-face. }\end{array}$ & 15.2 & 27.2 & 57.6 & 2.47 & 0.980 \\
$\begin{array}{l}\text { I believe remote teaching will help my } \\
\text { learners engage more with the Life }\end{array}$ & 32.0 & 42.4 & 25.6 & 3.04 & 1.019 \\
$\begin{array}{l}\text { Sciences content. } \\
\text { I have the knowledge and ability to teach } \\
\text { through remote. }\end{array}$ & 67.2 & 27.2 & 5.6 & 3.78 & 0.812 \\
$\begin{array}{l}\text { Given a choice, I would prefer remote } \\
\text { teaching than face-to-face. }\end{array}$ & 9.8 & 22.8 & 67.4 & 2.24 & 0.970 \\
$\begin{array}{l}\text { Assessing my learners through remote } \\
\text { platforms is beneficial. }\end{array}$ & 44.0 & 37.6 & 18.4 & 3.32 & 1.005 \\
$\begin{array}{l}\text { I feel confident in using the technology } \\
\text { tools/resources to conduct remote } \\
\text { teaching. }\end{array}$ & 58.0 & 34.7 & 7.2 & 3.66 & 0.882 \\
$\begin{array}{l}\text { I feel I still need to be trained to } \\
\text { effectively teach remotely. }\end{array}$ & 74.2 & 16.9 & 8.8 & 3.94 & 1.028 \\
\hline
\end{tabular}

From table 4 it shows that the pre-service teachers showed confidence in their preparedness to teach remotely as evidenced from the $65.6 \%$ who believed they were prepared, and $67.2 \%$ who indicated that they possessed the prerequisite knowledge and skills to teach remotely. Despite the confidence mentioned, the pre-service teachers however showed preference for face-to-face teaching over remote as depicted from the majority (67.4\%) who disagreed with the statement, "Given a choice, I would prefer remote teaching than face-to-face". Such sentiments could be because they still felt they were not adequately prepared because $74.2 \%$ agreed to the statement, "I feel I still need to be trained to effectively teach remotely".

\subsection{Exploratory Factor Analysis}

Factor analysis of questionnaire items was performed before making comparisons between the pre-service teachers' responses through One-way ANOVA. Exploratory Factor Analysis (EFA) was performed on items measuring perceptions, experiences and preparedness of remote teaching and learning in the Life Sciences methodology module, as a dimension reduction technique. The statements were factor analysed using the Principal Components Analysis with varimax rotation. Two diagnostic measures namely Kaiser-Meyer Olkin measure of sampling adequacy (KMO) and Bartlett's Test of Sphericity were carried out in order to assess the suitability of the data for factor analysis. The results showed the KMO value of 0.781 , above the recommended value of 0.60 (Tabachnick \& Fidell, 2013) and the Bartlett`s Test of Sphericity was statistically significant (p-value < 0.05) (Barlett, 1954). These results suggest the data was suitable for factor analysis. 
Table 5. Summary of exploratory factor analysis and reliability analysis results

\begin{tabular}{|c|c|c|c|c|}
\hline Factor (s) & $\begin{array}{c}\text { Factor } \\
\text { loadings }\end{array}$ & Eigenvalues & $\begin{array}{l}\text { Variance } \\
\text { explained (\%) }\end{array}$ & $\begin{array}{c}\text { Cronbach`s } \\
\text { Alpha } \\
\text { Coefficient }\end{array}$ \\
\hline
\end{tabular}

Factor 1: Lecturer competencies and support

My lecturers show competency in remote teaching and

0.797

learning.

My lecturers support me in this remote teaching and

0.788

learning.

My lecturers show positive attitudes about remote

0.787

6.365

26.520

0.865

teaching and learning.

My lecturers come prepared for remote teaching and

0.758

learning.

The online assessment given in Life Sciences methodology

module prepares me for the teaching profession.

The Blackboard space has enough material for each unit in the Life Sciences Methodology module.

The use of a WhatsApp group platform is very helpful.

\section{Factor 2: Willingness to teach remotely}

I believe remote teaching will help my learners engage more with the Life Sciences content.

I feel I can help my learners more when I teach through remote than face-to-face.

Given a choice, I would prefer remote teaching than face-to-face.

I intend to teach my learners through remote mode.

Assessing my learners through online platforms is beneficial.

\section{Factor 3: Preparedness to teach remotely}

I feel confident in using the technology tools/resources to conduct remote teaching.

I have the knowledge and ability to teach through remote.

I believe I am capable to teach my learners through online platforms.

\section{Factor 4: Benefits and Confidence in remote teaching and learning}

The advantages of remote teaching and learning outweigh the disadvantages.

I consider remote teaching as beneficial.

I do prefer remote teaching and learning more than face to face we normally had.

Remote teaching and learning is positively affecting my academic performance in the Life Sciences methodology module. 
Factor 5: Positive experiences with remote teaching and learning

I have a conducive learning environment at home for 0.725 remote teaching and learning.

My academic performance has improved greatly during remote teaching and learning process.

I am coping well with remote teaching and learning.

Factor 6: Capabilities in remote teaching and learning

I believe I can use technology effectively for remote teaching and learning.

I have the knowledge and ability to use technologies during the remote teaching of Life Sciences Methodology module.
Total variance explained
0.665

0.658

0.797 1.231

0.664

1.083

0.766
0.797

Table 5 displays a summary of the exploratory factor analysis and reliability analysis results. As shown a six-factor model with 24 remaining items was obtained after four iterations of EFA were performed and several items were removed because of either factor loadings below 0.5 (Costello \& Osborne, 2005) or that they were measuring what they were not intended to measure.

The first factor was called "lecturer competencies and support" with an eigenvalue of 6.365 explained $26.520 \%$ of the total variance; the second factor was labelled "willingness to teach online" with an eigenvalue of 3.173 contributed $13.221 \%$ of the total variance; the third factor was named "preparedness to teach online" with an eigenvalue of 2.183 accounted for $9.098 \%$; the fourth factor was labelled "benefits and confidence in online teaching and learning" with an eigenvalue of 1.734 explained $7.224 \%$; the fifth factor was called "positive experiences with remote teaching and learning" with an eigenvalue of 1.231 accounted for $5.129 \%$; and the sixth factor with an eigenvalue of 1.083 was named "capabilities in remote teaching and learning" contributed $4.512 \%$ of the total variance.

The six factors recorded a total variance of $65.703 \%$ exceeding the threshold value of $60 \%$ (Wild \& Diggines, 2015). The factor loadings range from 0.523 to 0.811 , exceeding the threshold value of 0.5 (Costello \& Osbourne, 2005) meaning that these items were strong enough to measure their respective factors.

To assess reliability, the Cronbach`s alpha coefficient for each construct was examined. As indicated in Table 5, the Cronbach`s alpha coefficient values ranged from 0.664 to 0.865 which is acceptable according to the recommended cut-off value of 0.70 (DeVellis, 2012), indicating that the study constructs were reliable.

\subsection{One-Way ANOVA}

In this study One-Way ANOVA tests were conducted in order to compare pre-service teachers perceptions and experiences of remote teaching across learning environments (residential areas) on benefits and confidence in remote teaching and learning, capabilities in remote teaching and learning, lecturer competencies and support, positive experiences with remote teaching and learning, willingness to teach remotely, and preparedness to teach remotely. This was meant to determine issues of adaptability to the new mode of teaching and learning. 
Table 6. One-Way ANOVA results

\begin{tabular}{llccccc}
\hline & \multicolumn{2}{c}{$\begin{array}{c}\text { ANOVA } \\
\text { Sum of Squares }\end{array}$} & df & Mean Square & F & Sig. \\
\hline Benefits of & Between Groups & 0.253 & 2 & 0.127 & 0.301 & 0.740 \\
confidence in & Within Groups & 50.00 & 119 & 0.420 & & \\
remote teaching & Total & 50.253 & 121 & & & \\
Capabilities in & Between Groups & 1.227 & 2 & 0.614 & 1.523 & 0.222 \\
remote teaching & Within Groups & 47.939 & 119 & 0.403 & & \\
and learning & Total & 49.166 & 121 & & & \\
Lecturer & Between Groups & 3.421 & 2 & 1.710 & 4.683 & 0.011 \\
competencies and & Within Groups & 43.459 & 119 & 0.365 & & \\
support & Total & 46.880 & 121 & & & \\
Positive & Between Groups & 0.849 & 2 & 0.425 & 0.683 & 0.507 \\
Experiences with & Within Groups & 73.998 & 119 & 0.622 & & \\
remote teaching & Total & 74.847 & 121 & & & \\
and learning & Between Groups & 0.283 & 2 & 0.141 & 0.250 & 0.779 \\
Willingness to & Within Groups & 67.375 & 119 & 0.566 & & \\
teach remotely & Total & 67.658 & 121 & & & \\
Preparedness to & Between Groups & 2.429 & 2 & 1.215 & 2.470 & 0.089 \\
teach remotely & Within Groups & 58.525 & 119 & 0.492 & & \\
& Total & 60.955 & 121 & & &
\end{tabular}

The One-Way ANOVA results indicated in Table 6 suggest that there is a statistically significant difference in pre-service teachers' learning environment (residential area) on lecturer competencies and support $(\mathrm{p}$-value $=0.011$ ) and there were no significant differences across learning environment on other scales as shown by the p-values > 0.05 . Tukey`s HSD Tests were conducted in order to investigate where the difference exists among the three residential areas (rural, township and suburban) in regard to lecturer competencies and support.

Post Hoc Tests on lecture competencies and support on remote teaching and learning showed evidence of statistical significant differences in perceptions of pre-service teachers regarding their lecturers' competencies and support received during their experiences of remote teaching between those living in rural areas and those living in suburban areas ( $\mathrm{p}$-value $=0.010$ ). Results on the pre-service teachers' demographic data shows that $28.8 \%$ lived in rural areas where they lack appropriate electronic gadgets and internet connectivity is problematic and $17.6 \%$ lived in suburban areas which are considered to be affluent hence could afford the requirements for remote teaching and learning. Such differences could be attributed to the differences in the levels of appreciation of the help and support received. A point to note is that in the rural settlements pre-service teachers could have appreciated every little bit of help from their lecturers unlike the ones coming from advantaged homes who expected more sophisticated lecturer competencies. Such a finding showed different levels of adaptations due to the learning environments.

\section{Discussion}

Because of the COVID-19 pandemic it became mandatory that pre-service teachers transition from face-to-face to remote mode of teaching and learning. Such changes have been described by Senge et al. (2012) as some kind of social and technological transformation. In this article, the level of adaptation to remote teaching and learning is determined by the pre-service teachers' perceptions, experiences and preparedness. Quite a large percentage (41.1\%) showed dissatisfaction with the rapid transition from face-to-face to remote teaching and learning mode compared to only $29.9 \%$ who indicated that they had sufficient time to prepare for the shift. At classroom level teacher acceptance of change has been attributed to factors such as culture of risk-taking, supportive leadership, and quality professional development (Craig, 2012; Gibson \& Brooks, 2012; Melville, Bartley, \& Weinburgh, 2012). As such, different pre-service teachers' adaptation to the transition was not uniform as Scherera, Howard, Tondeurc, and Siddiq (2021) 
pointed out that individuals may be affected by the social factors differently. The pre-service teachers' perceptions regarding remote teaching and learning are explained by Venkatesh and Davis (1996) in that the pre-service teachers who had positive perceptions about remote teaching and learning, found it easier to transition from face-to-face to remote mode. Conversely, those who had negative perceptions had difficulties when engaging in remote teaching and learning due to the different contextual environments. In response to the questions regarding their experiences of remote teaching and learning, the pre-service teachers appreciated the initiative that enabled them to interact with one another through WhatsApp groups, the use of chat and discussion platforms on the learning management systems and just being asked to make contributions during the lectures. It shows that by its very nature social constructivism acknowledges that meaningful learning takes place through interactions of people in a group (Vygotsky, 1986).

The level of adaptation could not be the same because pre-service teachers came from different backgrounds which defined their learning environments and as such impacted on their experiences of remote teaching and learning. For instance, the majority were Black Africans (91.1\%) living in township schools (51.2\%) and rural areas (28.8\%) who relied on data for internet connectivity for them to access remote teaching and learning platforms. A substantial number (38.4\%) relied on cellphones due to lack of the essential electronic gadgets.

Though some of the pre-service teachers (52\%) indicated that they were technologically capable, the majority (74.2\%) realised their shortcomings and indicated the need for training for remote teaching and learning. Related to this, many pre-service teachers were of the opinion that when given a choice, they would prefer face-to-face teaching and learning instead of remote mode. The findings support Paudel's (2021) argument that for successful implementation of online/remote teaching and learning, technological preparedness and computer literacy are key. This is also explained by Venkash and Davies' 1996 descriptive variables that influence the choices an individual makes in terms of behaviour.

The results from One-way ANOVA showed that pre-service teachers living in rural areas were more appreciative of the assistance they received from their lecturers than those living in affluent suburban areas during remote teaching and learning. Such findings imply that pre-service teachers in rural areas were less adapted to remote teaching and learning as they could not manage without the help and support they got from their lecturers. An important aspect to note is that in rural areas there is a lack of internet connectivity, lack of electronic devices and acceptable technological software (Dube, 2021). The argument is that the disparity between the socio-economic backgrounds of university students, may widen the digital divide and consequently affect some of the students' performances particularly those from disadvantaged backgrounds. Dube (2020) confirmed that students located in rural areas are deprived of the knowledge and skills their counterparts in urban areas receive. As such, Bao (2020) called for higher education institutions to provide pedagogical and material support to students.

\section{Conclusion}

From the findings of the study, it shows the difficult circumstances students in a developing country encounter when navigating the sudden change from face-to-face to remote teaching. Whilst this transition was facilitated by the COVID-19 pandemic, a point to note is that when any change is required in the teaching and learning process, students from disadvantaged backgrounds struggle to adjust particularly if the change requires acquisition of learning materials or equipment. The findings showed that the university students' (pre-service teachers) levels of adaptations to remote teaching and learning were influenced by their capabilities to acquire suitable electronic gadgets, availability of internet connectivity, and their technological knowledge and skills.

From a practitioner's perspective, the findings of the study inform teacher educators and practising teachers on the need to consider the contextual factors in which students are operating in. This calls for the importance of knowledge of students' socioeconomic backgrounds particularly when it comes to expectations regarding deadlines for completion and submission of activities and assessments. A point to note is the study is not arguing for lower expectations of the performance of students from disadvantaged communities but rather argues for the provision of resources and tailored support that enables every student to succeed regardless of their backgrounds.

From an academic perspective an important finding from the study is the designing and validation of an instrument (questionnaire), which can be used in other studies in different contexts such as in other developing countries in Africa and Asia.

\section{Acknowledgements}

We acknowledge the unwavering participation by pre-service teachers without whose reponses the study could not have materialised. 


\section{References}

Ali, A. (2020). Online and remote learning in higher education institutions: A necessity in light of Covid-19 pandemic. Canadian Centre of Science and Education, 10(3), 16-25. https://doi.org/10.5539/hes.v10n3p16

Allen, I. E., \& Seaman, J. (2010). Class difference: Online education in the United States, 2010. Babson Park. Massachsetts: Babson Survey Research Group. Retrieved from http://sloanconsortium.org/publications/survey/class_differences

Allen, I. E., \& Seaman, J. B. (2017). Digital compass learning: Distance education enrolment Report 2017.

Ananga, P., \& Biney, I. K. (2017). Comparing face-to-face and online teaching and learning in higher education. MIER Journal of Educational Studies, Trends and Practices, 7(2), 165-179. https://doi.org/10.52634/mier/2017/v7/i2/1415

Bao, W. (2020). COVID-19 and online teaching in higher education: A case study of Peking University. Human Behavior and Emerging Technologies, 2(2), 113-115. https://doi.org/10.1002/hbe2.191

Bartlett, M. S. (1954). A note on the multiplying factors for various chi square approximations. Journal of Royal Statistical Society, 16, 296-298. https://doi.org/10.1111/j.2517-6161.1954.tb00174.x

Bharuthram, S., \& Kies, C. (2013). Introducing e-learning in a South African education institution: challenges arising from an intervention and possible responses. British Journal of Educational Technology, 44(3), 410-420. https://doi.org/10.1111/j.1467-8535.2021.01307.x

Biggs, J. (1987). Student approaches to learning and studying, Australian Council for Educational Research. Hawthorn: Victoria.

Biggs, J. (1993). What do inventories of students' learning process really measure? A theoretical review and $\begin{array}{lllll}\text { clarification. British Journal of Educational Psychology, } & \text { 83, }\end{array}$ https://doi.org/10.1111/j.2044-8279.1993.tb01038.x

Britt, R. (2006). Online education: A survey of faculty and students. Radiologic Technology, 77(3), 183-190.

Brooks, C., \& Gibson, S. (2012). Professional learning in digital age. Canadian Journal of Learning and Technology, 38(2), 1-17. https://doi.org/10.21432/T2HS3Q

Chiasson, K., Terras, K., \& Smart, K. (2015). Faculty perception of moving a face-to- face course to online instruction. Journal of College Teaching and Learning- Third Quarter, 12(4), 231-240. https://doi.org/10.19030/tlc.v12i3.9315

Chohan, B. I. (2014). Students' perceptions regarding teaching and learning effectiveness in online face to face learning environment. FWU Journal of Social Sciences, 8(1), 50-56.

Ciroma, Z. I. (2014). ICT and education: Issues and challenges. Mediterranean Journal of Social Sciences, 5(26), 98. https://doi.org./10.5901/mjss.2014.v5n26p98

Coman, C., Tîru, L. G., Mesesan-Schmitz, L., Stanciu, C., \& Bularca, M. C. (2020). Online teaching and learning in higher education during the coronavirus pandemic: Students' perspective. Sustainability, 12(24), 10367. https://doi.org/10.3390/su122410367

Craig. T. S. (2012). Explanatory writing in problem-solving: understanding through reflection. Community for Undergraduate Learning in the Mathematical Sciences (CULMS) Newsletter, 5, 4-11.

Creswell, J. (2014). Research design, qualitative, quantitative and mixed method approach, $4^{\text {th }}$ ed. Thousand Oaks, California: Sage Publications.

Deimann, M., \& Bastiaens, T. (2010). The role of volition in distance education: An exploration of its capacities. The International Review of Research in Open and Distance learning, 11. https://doi.org/10.19173/irrodl.v11i1.778

Devillis, R. (2012). Scale development theory and applications. New York: Sage Publications.

Dube, B. (2020). Rural online learning in the context of COVID-19 in South Africa: Evoking an inclusive education approach. Multidisciplinary Journal of Education Research, 10(2), 135-157. https://doi.org/10.17583/remie.2020.5607

Faux, T. L., \& Black-Hughes, C. (2000). A comparison of using the internet versus lectures to teach social work history. Research on Social Work Practice, 10, 454-466. https://doi.org/10.1177/104973150001000406

Fidalgo, P., Thormann, J., Kulyk, O., \& Lencastre, J. A. (2020). Students' perceptions on distance education: A 
multinational study. International Journal of Educational Technology in Higher Education, 17(18). https://doi.org/10.1186/s41239-020-00194-2

Fish, W. W., \& Gill, P. B. (2009). Perceptions of online instruction. The Turkish Online Journal of Education Technology, 8(1), 1303-6521.

Hartshorne, R., \& Ajjan, H. (2009). Examining student decision to adapt web 2.0 technologies: theory and empirical tests. Journal of Computing in Higher Education, 21, 183-198. https://doi.org/10.1007/s12528-009-9023-6

Herrington, J., \& Standen, P. (2000). Moving from an instructivist to a constructivist multimedia learning environment. JournaI of Educational Multimedia and Hypermedia, 9(3), 195-205.

Hinson, J. M., \& LaPrairie, K. N. (2005). Learning to teach online: Promoting success through professional development. Journal of Research and Practice, 29(6), 483-493. https://doi.org/10.1080/10668920590934198

Hodges, C., Moore, S., Lockee, B., Trust, T., \& Bond, A. (2020). The difference between emergency remote teaching and online learning. Educause Review, 1-15.

Horspool, A., \& Yang, S. S. (2010). A comparison of university student perceptions and success learning music online and face-to-face. MERLOT Journal of online learning and teaching, 6, 15-29. http://jolt.merlot.org/vol6no1/horspool_0310.pdf

Huang, R. H., Liu, D. L., Tlili, A., Yang, J., Wang, H. H., \& Chang, T. (2020). Handbook on Facilitating flexible learning during education Disruption: The Chinese experience in maintaining learning in COVID-19 outbreak. Beijing: Smart Learning Institute of Beijing Normal University.

Kinsella, E. A., \& Pitman, A. (2012). Phronesis as professional knowledge: practical wisdom in the professions. Rotterdam: Sense Publishing. https://doi.org/10.1007/978-94-6091-731-8

Koehler, M. J., Mishra, P., Hershey, K., \& Peruski, L. (2004). With a little help from your students: A new model for faculty development and online course design. Journal of Technology and Teacher Education, 12, 25-55.

Leasure, A., Davis, L., \& Thievon, S. (2000). Comparison of students' outcomes and preference in traditional vs world wide web-based baccalaureate nursing research course. Journal of Nursing Education, 39, 149-154. https://doi.org/10.3928/0148-4834-20000401-04

Letseka, M., Letseka, M., \& Pitsoe, V. (2018). The challenges of e-learning in South Africa. In M. Sinecen (Ed.) Trends in E-learning (pp. 121-138). https://doi.org/10.5772/intechopen.74843

Levy, Y. (2005). Comparing drop-outs and persistence in e-learning courses. Computers \& Education, 48, 185-204. https://doi.org/10.1016/j.compedu.2004.12.004

Li, Q., \& Akins, M. (2005). Sixteen myths about online teaching and learning in higher education: Don't believe everything you hear. Tech Trends: Linking Research and Practice to Improve Learning, 49(4), 51-60. https://doi.org/10.1007/BF02824111

Majid, S., Yang, P., Lei, H., \& Haoran, N. (2014). Knowledge sharing by students: preference for online discussion boards vs face-to-face participation. A paper presented at the Research and Practice, $16^{\text {th }}$ International conference on Asia-Pacific Digital Libraries, ICADL, 5-7 November, Chiang Mai, Thailand. https://doi.org/10.1007/978-3-319-12823-8_16

Melville, W., Bartley, A., \& Weinburgh, M. (2012). Change forces: Implementing change in a secondary school for the common good. Canadian Journal of Educational Administration and Policy, 133, 1-26.

Mhlanga, D., \& Moloi T. (2020). COVID-19 and the digital transformation of education: What are we learning on 4IR in South Africa? Education Sciences, 1(7), 180. https://doi.org/10.20944/preprints202004.0195.v1

Costello, A. B., \& Osborne, J. (2005). Best practices in exploratory factor analysis: Four recommendations for getting the most from your analysis, Practical Assessment, Research, and Evaluation, 10(7), 1531-7714. https://doi.org/10.7275/jyj1-4868

Park, J., \& Park M. (2016). Qualitative versus quantitative research methods: Discovery or justification? Journal of Marketing Thoughts, 3(1), 1-7. https://doi.org/10.15577/jmt.2016.03.01.1

Paudel, P. (2021). Online education: Benefits, challenges and strategies during and after COVID-19 in higher education. International Journal on Studies in Education, 3(2), 70-85. https://doi.org/10.46328/ijonse.32

Paulikas, J. (2018). The factors determining employees' positive attitude to innovations: A case of Klaipeda Public 
Transport Companies. Sciendo, 79(1), 86-102. https://doi.org/10.1515/mosr-2018-0006

Platt, A. C., Raile, N. W., \& Yu, N. (2014). Virtually the same? Students' perceptions of the equivalence of online classes to face-to-face classes. MERLOT Journal of Online Learning and Teaching, 20(3), 489-503.

Rabah, J. (2015). Benefits and challenges of information and communication technologies (ICT) integration in Quebec English schools. Turkish Online Journal of Education Technology, 14(2), 24-31.

Roddy, C., Amiet, D. L., Chung, J., Holt, C., Shaw, L., Mckenzie, S., Garivaldis, F., Lodge, J. M., \& Mundy, M. E. (2017). Applying best practice online learning, teaching, and support to intensive online environments: An integrative review. Frontiers in Education, 2(59), 1-7. https://doi.org/10.3389/feduc.2017.00059

Sadaf, A., Newby T., \& Ertmer, P. A. (2012). Exploring pre-service teachers' beliefs about using Web 2.0 technologies in k-12 classroom. Computers \& Education, 59(3), 937-945. https://doi.org/10.1016/j.compedu.2012.04.001

Scherera, R., Howard, S. K., Tondeur, J., \& Siddiq, F. (2021). Profiling teachers' readiness for online teaching and learning in higher education: Who's ready? Computers in Human Behavior, 118, 106675. https://doi.org/10.1016/j.chb.2020.106675

Schwab, K. (2016). The Fourth Industrial Revolution. Munich: Pantheon Publishing House.

Senge, P., Cambron-McCabe, N., Lucas, T., Smith, B., Dutton, J., \& Kleiner, A. (2012). Schools that learn: A fifth discipline fieldbook for educators, parents, and everyone who cares about education. New York, NY: Crown Business.

Shihab, M. (2008). Web 2.0 tools to improve teaching and collaboration in high school English language classes. Doctoral thesis. Nova Southeastern University: NSU Florida.

Singh, V., \& Thurman, A. (2019). How many ways can we define online learning? A systematic literature review of definitions of online learning (1988-2018). American Journal of Distance Education, 33(4), 289-306. https://doi.org/10.1080/8923647.2019.1663082

Srichanyachon, N. (2014). EFL learners' perceptions using LMS. Turkish Online Journal of Educational Technology, 13(4), 30-35.

Tabachnick, B. G., \& Fidell, L. S. (2013). Using multivariate statistics $\left(6^{\text {th }}\right.$ ed.). Boston, MA: Pearson.

Taylor, S., \& Yu, D. (2009). The importance of socio-economic status in determining educational achievement in South Africa. Stellenbosch University, Bureau of Economic Research, Stellenbosch: Stellenbosch Economic Working Papers: 01/09, 1-77.

UNESCO (2020b). COVID-19 webinar: a new world for teachers, education's frontline workers. Retrieved April 6, 2020, from https://en.unesco.org/news/covid-19-webinar-new-world-teachers-educations-frontline-workers

Venkatesh, V., \& Davies, F. (1996). A model of the antecedents of perceived ease of use: development and test. Decision Science, 27, 451-481. https://doi.org/10.1111/j.1540-5915.1996.tb00860.x

Vygotsky, L. (1978). Mind in society: The development of higher psychological processes. Cambridge, MA: Harvard University Press.

Wiid, J., \& Diggines, C. (2015). Marketing research. Lansdowne, Cape Town: JUTA.

Young, S., Cantrell, P. P., \& Shaw, D. G. (2001). Online instruction: New roles for teachers and students. Academic Exchange Quarterly, 5, 11-16.

Zhang, R., Li, Y., Zhang, L. A., Wang, L., \& Molina, M. J. (2020). Identifying airborne transmission as the dominant route for the spread of COVID-19. Proceedings of the National Academy of Sciences of the United States of America (PNAS), 117(26), 14857-14863. https://doi.org/10.1073/pnas.2009637117 


\section{Appendix A}

\section{Questionnaire on remote teaching and learning during COVID-19 pandemic}

This questionnaire is meant to collect information from you, the student who is enrolled in the Life Sciences Methodology and Practicum module. The information will inform your lecturers on how best they can assist you during remote teaching and learning period. Your honesty response is highly appreciated since there is no right or wrong answer. The questionnaire is made up of four sections, A, B, C and D. Please complete all of them.

\section{Participant consent}

The purpose of the study has been explained to me. I understand the research project and my role in it. I understand the confidentiality clause as stated by the researcher. I understand that I can retrieve my consent and participation in the research and there will be no penalty against me.

If you consent to the above terms and conditions of the research, please indicate by placing an $\mathbf{X}$ next to Yes.

I consent to participate fully in the study No

Yes

Section A: Biographical information

Please place a cross $(\mathrm{X})$ in the appropriate response.

1. State your gender.

Female 1

Male 2

Other, specify................. 3

2. Which race group do you belong to?

Black 1

Coloured 2

Indian/Asian 3

White 4

3. Indicate the area you are staying in

Informal settlement 1

Rural 2

Farm 3

Township 4

Suburban 5

4. I mostly use the following gadget during the teaching and learning process (choose one)

$\begin{array}{ll}\text { Cellphone } & 1 \\ \text { Tablet/iPad } & 2 \\ \text { Laptop } & 3 \\ \text { Desktop } & 4\end{array}$

5. My main source of connectivity is (choose one)

Data 1

Wi-Fi 2

Internet cafe 3 
6. Indicate your level of study

$\begin{array}{ll}\text { Third Year } & 1 \\ \text { Fourth Year } & 2 \\ \text { PGCE } & 3\end{array}$

Section B: Perceptions of remote teaching and learning in the Life Sciences Methodology module

7. Please list your level of proficiency in engaging with remote learning.

\begin{tabular}{|c|c|c|c|c|c|c|}
\hline & & $\begin{array}{l}\text { Strongly } \\
\text { Disagree }\end{array}$ & Disagree & Neutral & Agree & $\begin{array}{l}\text { Strongly } \\
\text { Agree }\end{array}$ \\
\hline 7.1. & $\begin{array}{l}\text { I believe I can use technology effectively for remote teaching } \\
\text { and learning }\end{array}$ & 1 & 2 & 3 & 4 & 5 \\
\hline 7.2 & $\begin{array}{l}\text { I have the knowledge and ability to use technologies during the } \\
\text { remote teaching of Life Sciences Methodology module. }\end{array}$ & 1 & 2 & 3 & 4 & 5 \\
\hline 7.3 & $\begin{array}{l}\text { I do prefer remote teaching and learning more than the face- to- } \\
\text { face we normally had. }\end{array}$ & 1 & 2 & 3 & 4 & 5 \\
\hline 7.4 & I am challenged in terms of digital competence. & 1 & 2 & 3 & 4 & 5 \\
\hline 7.5 & I consider remote teaching as beneficial. & 1 & 2 & 3 & 4 & 5 \\
\hline 7.6 & $\begin{array}{l}\text { The advantages of remote teaching and learning outweigh the } \\
\text { disadvantages. }\end{array}$ & 1 & 2 & 3 & 4 & 5 \\
\hline 7.7 & $\begin{array}{l}\text { I am in control of my own learning during remote teaching and } \\
\text { learning process. }\end{array}$ & 1 & 2 & 3 & 4 & 5 \\
\hline 7.8 & $\begin{array}{l}\text { I believe remote teaching and learning is effective in preparing me } \\
\text { for the teaching profession. }\end{array}$ & 1 & 2 & 3 & 4 & 5 \\
\hline 7.9 & $\begin{array}{l}\text { Though the shift from face-to-face to remote teaching and learning } \\
\text { happened so suddenly, I had sufficient time to prepare for the shift. }\end{array}$ & 1 & 2 & 3 & 4 & 5 \\
\hline 7.10 & Remote learning challenged me in terms of my digital competence. & 1 & 2 & 3 & 4 & 5 \\
\hline 7.11 & $\begin{array}{l}\text { Remote teaching and learning is positively affecting my academic } \\
\text { performance in the Life sciences methodology module. }\end{array}$ & 1 & 2 & 3 & 4 & 5 \\
\hline 7.12 & $\begin{array}{l}\text { I am satisfied with the platform lecturers use to conduct remote } \\
\text { lectures. }\end{array}$ & 1 & 2 & 3 & 4 & 5 \\
\hline
\end{tabular}

Section C: Experiences in remote teaching and learning in the Life Sciences Methodology Module

8. What are your experiences in remote teaching and learning in the Life Sciences Methodology module?

\begin{tabular}{|c|c|c|}
\hline $\begin{array}{l}\text { Strongly } \\
\text { Disagree }\end{array}$ & Disagree Neutral & \\
\hline
\end{tabular}

8.1 I have connectivity challenges.

8.2 I am coping well with remote teaching and learning.

$8.3 \mathrm{I}$ am experiencing remote teaching and learning in the $21 \mathrm{st}$ century as I expected.

8.4 I prefer the engagement in discussions during remote lectures.

8.5 I prefer it when I am asked to make contributions.

8.6 I prefer when I make comments on the chat platform than talking.

8.7 I feel overwhelmed by the different communication channels.

$\begin{array}{lllll}1 & 2 & 3 & 4 & 5 \\ 1 & 2 & 3 & 4 & 5 \\ 1 & 2 & 3 & 4 & 5 \\ 1 & 2 & 3 & 4 & 5 \\ 1 & 2 & 3 & 4 & 5 \\ 1 & 2 & 3 & 4 & 5 \\ 1 & 2 & 3 & 4 & 5\end{array}$


8.8 The use of a WhatsApp group platform is very helpful.

\section{1}

1

8.9 I listen to the lecture recordings posted on Blackboard.

8.10 My academic performance has improved greatly during remote teaching and learning process.

8.11 My lecturers show competency in remote teaching and learning.

8.12 My lecturers come prepared for remote teaching and learning.

$8.13 \mathrm{My}$ lecturers support me in this remote teaching and learning.
8.14 I would prefer if lecturers just upload materials on Blackboard only without lectures on Blackboard collaborate.

8.15 The Blackboard space has enough material for each unit in the Life Sciences Methodology module.
8.16 My lecturers show positive attitudes about remote teaching and learning.
8.17 The remote teaching and learning has distanced me from the lecturers.
8.18 I have a conducive learning environment at home for remote teaching and learning.
8.19 The online assessment given in Life sciences methodology prepares me for the teaching profession.
8.20 I receive effective feedback on the assessment from my lecturers $\quad \begin{array}{lllll}1 & 2 & 3 & 4 & 5\end{array}$
8.21 The data I receive from the university eases the financial strains. $\begin{array}{llllll}1 & 2 & 3 & 4 & 5\end{array}$

Section D: Preparedness to teach remotely

9. How prepared are you to teach remotely?

\begin{tabular}{|c|c|c|c|c|c|c|}
\hline & & $\begin{array}{l}\text { Strongly } \\
\text { Disagree }\end{array}$ & Disagree & Neutral & Agree & $\begin{array}{c}\text { Strongly } \\
\text { Agree }\end{array}$ \\
\hline 9.1 & I believe I am capable to teach my learners through online platforms. & 1 & 2 & 3 & 4 & 5 \\
\hline 9.2 & I intend to teach my learners through remote mode. & 1 & 2 & 3 & 4 & 5 \\
\hline 9.3 & $\begin{array}{l}\text { I feel I can help my learners more when I teach through remotely } \\
\text { than face-to-face. }\end{array}$ & 1 & 2 & 3 & 4 & 5 \\
\hline 9.4 & $\begin{array}{l}\text { I believe remote teaching will help my learners engage more with } \\
\text { the Life Sciences content. }\end{array}$ & 1 & 2 & 3 & 4 & 5 \\
\hline 9.5 & I have the knowledge and ability to teach through remote mode. & 1 & 2 & 3 & 4 & 5 \\
\hline 9.6 & Given a choice, I would prefer remote teaching than face-to-face. & 1 & 2 & 3 & 4 & 5 \\
\hline 9.7 & Assessing my learners through online platforms is beneficial. & 1 & 2 & 3 & 4 & 5 \\
\hline 9.8 & $\begin{array}{l}\text { I feel confident in using the technology tools/resources to conduct } \\
\text { remote teaching. }\end{array}$ & 1 & 2 & 3 & 4 & 5 \\
\hline 9.9 & I feel I still need to be trained to effectively teach remotely. & 1 & 2 & 3 & 4 & 5 \\
\hline
\end{tabular}

\section{Copyrights}

Copyright for this article is retained by the author(s), with first publication rights granted to the journal.

This is an open-access article distributed under the terms and conditions of the Creative Commons Attribution license (http://creativecommons.org/licenses/by/4.0/). 